\title{
The Development of Customer Loyalty Model for Mobile Travel Agent Application
}

\author{
Budhi Prihartono, Muhammad Azhar Ashari, Aldila Rizkiana * \\ Industrial and Engineering Management, Institut Teknologi Bandung, Indonesia \\ Jl. Ganesha 10, Bandung 40132, Indonesia \\ *Corresponding author: aldila@ti.itb.ac.id
}

\section{ARTICLE INFO}

\section{Article history}

Received March 22, 2019

Revised August 4, 2019

Accepted August 20, 2019

Available Online September 15, 2019

\section{Keywords}

Customer loyalty

Customer engagement

Mobile commerce

Mobile travel agent

Multigroup SEM

\begin{abstract}
The growth of smartphone users in Indonesia opens up business opportunities for service providers, particularly via m-commerce. However, along with these great opportunities and rivalry, service providers are required to make consumers faithful to the products and services they deliver. This research aims to develop a conceptual model for an application based on m-commerce, particularly mobile travel agent applications. The research model is based on applying five dimensions of Mobile Service Quality (M-S-QUAL), customer engagement, and commitment as the predecessor factors of customer loyalty. The study was conducted on 760 MTA application users who participated in an online survey. The data were divided into two groups based on income level to be further analyzed using the Multigroup Structural Equation Modeling (SEM). The Multigroup SEM analysis shows that the concept of customer loyalty was explained differently by the two groups with different income levels.
\end{abstract}

This is an open-access article under the CC-BY-SA license.

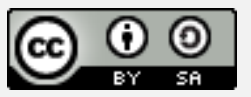

\section{Introduction}

The penetration rate of the handheld market in Indonesia was estimated to increase dramatically from 69.4 million in 2016 to 103 million in 2018 [1]. It encourages the development of mobile-commerce (m-commerce) as a new way to carry out the transaction. M-commerce refers to the ability to conduct commercial transactions using mobile phones connected to a wireless network [2]. Indonesia has become one of the fastest-growing m-commerce markets globally, with an increase of 155 percent in 2016 [3]. This growing market opens up opportunities for start-up companies to offer customers innovative products and services. An online travel agent (OTA) was one of the start-up categories widely used by people to trade [4]. The start-up companies included in the OTA category are Traveloka, Pegi-Pegi, and Tiket.com. Customer loyalty was the key to OTA success in staying competitive [5] [6] [7].

Previous research has identified several factors that influence customer loyalty. These factors include customer satisfaction [8-15], service quality [10, 11], trusts [10], 
commitment [10-12] and customer engagement [9]. Giovanis and Athanasopoulou [11] examined a model consisting of e-trust and e-satisfaction and six dimensions of E-S-QUAL consisting of reliability, responsiveness, privacy, quality of information, ease of use, and web design on the e-commerce website. The results showed that E-S-QUAL has a positive impact on e-trust and e-satisfaction. Furthermore, e-trust and e-satisfaction had a positive effect on e-loyalty. Lee and Wong [10] used the E-S-QUAL factor by adding trust and commitment variables to test the effect on customer loyalty on the e-commerce website. The result showed that the E-S-QUAL factor significantly impacts satisfaction and, together with trust and commitment, significantly impacts loyalty. Moreover, Thakur [9] developed a model to examine the impact of customer engagement, customer satisfaction, usability, and convenience on customer loyalty in the online shopping application. The results indicated that customer engagement has a significant impact on customer loyalty.

No studies have been conducted on customer loyalty to Mobile Travel Agents (MTAs) based on previous studies. This study developed a conceptual model for the ecommerce-based application, especially in applications for mobile travel agents. This study aimed to identify the factors affecting customer loyalty in the MTA application. There were two critical contributions to this research. First, this work integrated a customer loyalty model from Giovanis and Athanasopoulou [11] with commitment variables from Lee and Wong [10], customer engagement second-order variable from Thakur [9], and M-S-QUAL service quality dimension from Thakur [9]. M-S-QUAL was selected from E-S-QUAL [8, 9] and SERVQUAL [16, 17]. Second, this research used Multigroup Structural Equation Model to explore the characteristics of customer loyalty across groups with different income levels. The article is organized in the following: section 2 is a methodology that elaborates on the data and methods used to analyze the model; Section 3 describes the study results and discussion, and section 4 comprises conclusions and future work.

\section{Methods}

\subsection{Model and Hypothesis}

We developed a structural model to show the variable relationship. We also analyzed the model used the Structural Equation Models (SEM) and the Multigroup SEM. This section focused on structural equation model construction and variable-relationship hypothesis. The structural model can be seen in Fig. 1. The model used the Giovanis and Athanasopoulou [11] customer loyalty model as the basic model. The model was further expanded by adding a commitment variable from Lee and Wong [10], a second-order customer engagement variable from Thakur [9], and the M-S-QUAL quality service variable from Huang, et al. [18]. The descriptions and indicators for each variable used in this analysis are shown in Table 1 . Table 2 presents the research hypothesis.

The Customer Loyalty Model characteristics provided further information across groups, and a Multigroup SEM analysis was conducted. This study used income as a grouping indicator because customer loyalty has a negative relationship with price sensitivity [8]. It means that income-sensitive customers tend to have low loyalty. Multigroup SEM analysis was performed by dividing the sample into two groups. Respondents with income below 9,000,000 IDR were categorized into the lower-middle group. Meanwhile, respondents with income over 9,000,000 IDR were grouped into the upper-middle group. 
Table 1. Variable and Indicators

Variable Definition

The ability of m-commerce service providers to

Efficiency provide application interfaces that can provide information and settle transactions quickly and easily.

The reliability of $\mathrm{m}$-commerce service providers in

Reliability/ providing applications that can provide total product

Fulfillment

Contact

precisely as promised.

Service provider support to respond directly to the needs and concerns of the customer.

M-commerce service provider's capacity to offer

Responsiveness applications that facilitate practical applicationsolving problems, including order details, cancellations, refunds.

The ability of m-commerce service providers to develop applications that maintain consumer

Security/ privacy protection in performing transactions, including safeguarding all issues related to user data confidentiality and payment methods used from all forms of abuse.

Customer

Satisfaction

An emotional/psychological condition in which the consumer is happy and satisfied with the products and services provided meets individual standards when using the M-Commerce Program.

An accumulation of trust that the customer feels for

Trust the reliability of the knowledge, products, and services obtained from the experience of the application of $\mathrm{m}$-commerce.

Commitment

The ability to maintain good relations and use the same platform's future products and services for $\mathrm{m}$ commerce.

Psychological problems arise from ongoing encounters

Customer

Engagement and two-way interactions between consumers and service providers to improve customers ' willingness to use products or services from the same mcommerce program.

Positive customer experience achieved exclusively

Monetary

Experience through a series of attractive financial-related offers provided by m-commerce applications when customers use products and services.

Utilitarian

Experience

Positive customer experience related to the availability of information can help make the decision-making process purchase products and services through the m-commerce application.

$\begin{array}{cl}\text { Customer } & \text { The attitude of each individual/customer to purchase } \\ \text { Loyalty } & \text { and use products and services from the same }\end{array}$ Loyalty application and recommend the application to others.

\begin{tabular}{ll}
\multicolumn{1}{c}{ Indicator } & Ref \\
EFF1-EFF5 & {$[18]$,} \\
EFF6 & {$[20],[8]$,} \\
EFF7 & {$[19]$}
\end{tabular}

FUL1-FUL3 [18],

[20]

CON1-

CON3

RES1-RES3

[18],

RES4-RES6 [20]

[19]

[18],

$\begin{array}{ll} & \text { [20] } \\ \text { PRI1- PRI3 } & \text { [22], }\end{array}$

$\begin{array}{ll}\text { PRI4 [22], } & \text { [21], }\end{array}$

[19]

SAT1-SAT3 [23],

SAT4 [25],

SAT5 [24]

TRU1-TRU5 [22],

[26]

COM1-

COM3

* second-

order

construct

[9], [28]

reflected by

first-order

constructs

MON1-

MON4

[9]

UTI1-UTI3

[9]

LOY1-LOY3 [30]

LOY 4

[31]

LOY5

[5] [29] 
Table 2. Hypothesis and Supporting Research

\section{Hypothesis}

\section{Supporting}

Research

H1.a: Efficiency positively affects customer satisfaction

H1.b: Efficiency positively affects trust

H2.a: Reliability/ fulfillment positively affects customer

satisfaction

H2.b: Reliability/ fulfillment positively affects trust

H3.a: Contact positively affects customer satisfaction

H3.b: Contact positively affects trust

H4.a: Responsiveness positively affects customer satisfaction

H4.b: Responsiveness positively affects trust

H5.a: Privacy/security positively affects customer satisfaction

H5.b: Privacy/security positively affects trust

H6 : Customer satisfaction positively affects customer loyalty

H7 : Customer satisfaction positively affects trust

H8 : Trust positively affects customer satisfaction

H9 : Trust positively affects commitment

H10 : Commitment positively affects customer loyalty

H11 : Customer engagement positively affects customer loyalty

H12.a: Customer engagement reflected by the monetary experience

H12.b: Customer engagement reflected by the utilitarian

experience

\author{
[10] \\ [11] \\ [10], [32]
}

[11], [33]

[23]

[21]

[11], [32]

[11], [32]

[10], [11], [33]

[10], [11], [33]

[27], [11]

[11]

[34]

[10]

[10], [5], [35]

[26], [28]

[9]

[9]

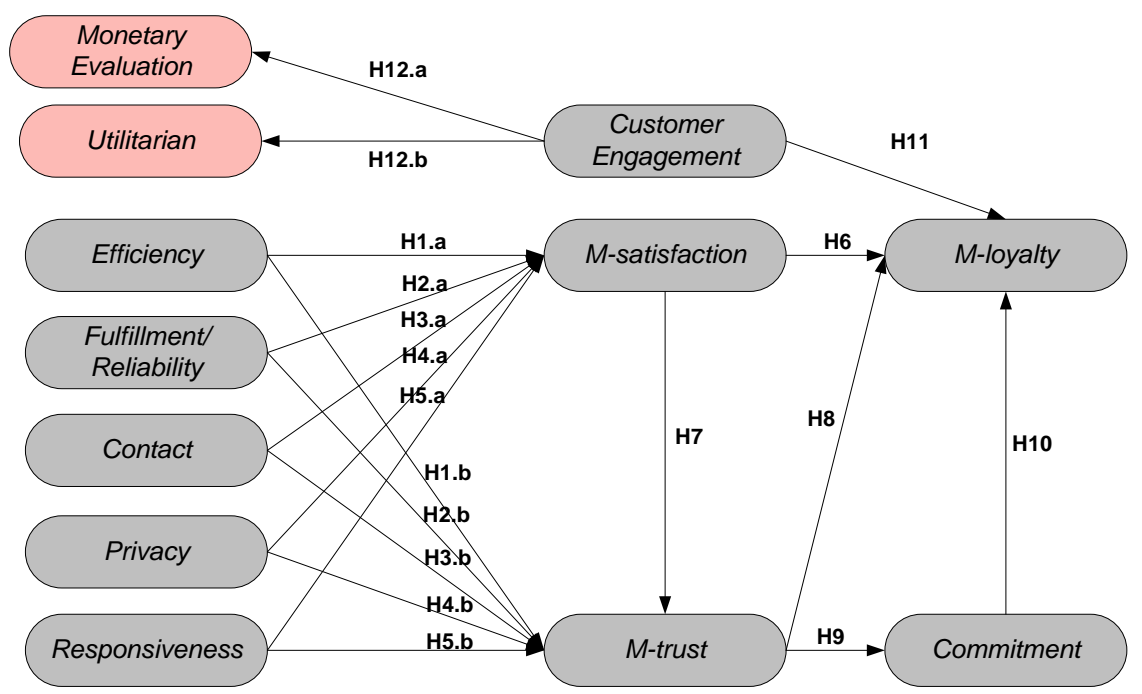

Fig. 1 Structural Model

\subsection{Data collection method}

This research used a quantitative approach. The primary data was obtained directly from the target sample. The population was users of mobile travel agent applications that had purchased products and services. The research instrument used open-ended and closed-ended questionnaires. The first part of the survey included an introduction and a short explanation of the research. The second part contained a few quick questions about the identity of the respondents. The last part was the central part of the questionnaire, which included statements representing the measurement indicators. 
The Likert six-point scale was used as a measurement scale to avoid neutral responses. The "1" scale means Strongly Disagree, and the "6" scale means Strongly Agree. Respondents were asked to rate each question. Method for collecting data used convenience sampling. This method was chosen because of the ease and time efficiency. Questionnaires were distributed online via electronic media such as e-mail and sample target links. Seven hundred sixty samples were collected, 35 of which were used for initial data analysis.

\subsection{Data analysis technique}

Data analysis was conducted by SEM and Multigroup SEM using MPlus software. Furthermore, multi-group SEM consists of measurements of invariance, the structure of invariance, and the path of the coefficient of invariance. A multi-group analysis was conducted to prove the hypothesis of differences in customer loyalty in the sample group with different income levels. The survey was divided into two groups based on the type of income referred to in Model Development.

\section{Results and Discussion 3.1 SEM Analysis}

Table 3 shows the results of the hypothesis test. Efficiency affected the satisfaction of the customer. This finding was compatible with Lee and Wong [10] and proved a decisive impact on customer satisfaction. Service providers must provide the MTA web interface with easy and quick access to information and transactions. Efficiency was the second significant influence of trust after privacy/security. It was consistent with Gustafsson, et al. [36]. Therefore, there was a significant influence in m-commerce between efficiency and trust. Application providers can consider these findings. The objective was to provide an easily and quickly accessible MTA application interface for information and transaction settlement.

Reliability/fulfillment had a positive impact on customer satisfaction. Giovanis and Athanasopoulou [11] found a positive relationship between reliability and customer satisfaction. Service providers must provide reliable services that can meet the expectations of the customers. The quality of the service in question included the consistency of the order details (order name, order quantity date, order code), the pricebased information on the order page, and the speed of delivery of the e-voucher. Reliability was part of the quality of service aspect had a significant impact on customer satisfaction. Giovanis and Athanasopoulou [11] found a positive relationship between trust and reliability. Kim, et al. [33] also supported this finding.

The contact did not impact customer satisfaction. Service provider assistance in solving complaints and helping customers solve problems did not affect customer satisfaction. The other four dimensions of service quality were considered far more critical in customer satisfaction. This finding was similar to the finding in Kumbhar [37], which found that contact had no significant effect on customer satisfaction. Al-nasser, et al. [21] found that contact had a significant impact on e-commerce trust. Access to service provider assistance in responding to concerns and helping customer problems were expected to increase consumer trust in online transactions. However, In this study, the relationship did not prove it. 
Table 3. Result of hypothesis test for SEM Model

\begin{tabular}{clccc} 
Code & \multicolumn{1}{c}{ Hypothesis } & Loading & P.value & Conclusion \\
\hline H1.a & Efficiency $\rightarrow$ customer satisfaction & 0.525 & 0.000 & Accepted \\
H1.b & Efficiency $\rightarrow$ trust & 0.150 & 0.023 & Accepted \\
H2.a & Reliability/ fulfillment $\rightarrow$ customer & 0.162 & 0.009 & Accepted \\
H2.b & Reliability/ fulfillment $\rightarrow$ trust & 0.133 & 0.037 & Accepted \\
H3.a & Contact $\rightarrow$ customer satisfaction & -0.041 & 0.346 & Rejected \\
H3.b & Contact $\rightarrow$ trust & 0.014 & 0.755 & Rejected \\
H4.a & Responsiveness $\rightarrow$ customer satisfaction & 0.134 & 0.007 & Accepted \\
H4.b & Responsiveness $\rightarrow$ trust & 0.135 & 0.008 & Accepted \\
H5.a & Privacy/ Security $\rightarrow$ customer satisfaction & 0.209 & 0.000 & Accepted \\
H5.b & Privacy/Security $\rightarrow$ trust & 0.196 & 0.000 & Accepted \\
H6 & Customer satisfaction $\rightarrow$ customer loyalty & 0.329 & 0.000 & Accepted \\
H7 & Customer satisfaction $\rightarrow$ trust & 0.381 & 0.000 & Accepted \\
H8 & Trust $\rightarrow$ customer loyalty & 0.204 & 0.001 & Accepted \\
H9 & Trust $\rightarrow$ commitment & 0.737 & 0.000 & Accepted \\
H10 & Commitment $\rightarrow$ customer loyalty & 0.167 & 0.000 & Accepted \\
H11 & Customer engagement $\rightarrow$ customer loyalty & 0.266 & 0.000 & Accepted \\
H12.a & Customer engagement is reflected by monetary & 0.795 & 0.000 & Accepted \\
& experience & & & \\
H12.b & Customer engagement is reflected by utilitarian & 0.968 & 0.000 & Accepted \\
\hline & experience & & & \\
\hline
\end{tabular}

Responsibility influenced customer satisfaction. It was confirmed by Giovanis and Athanasopoulou [11] and Lee [32]. Giovanis and Athanasopoulou [11] showed that customer satisfaction did not directly affect trust. However, it had an indirect effect. This research had different perspectives. Responsiveness and customer satisfaction were directly related. The availability of access to communication with service providers made customers feel safe and convinced to transact using the MTA application. Privacy/security had a significant direct effect on customer satisfaction. The issue of personal data confidentiality, particularly credit card data used, was an essential aspect of MTA application [10]. Service providers must ensure data security to satisfy customers.

Privacy/security had a positive impact on trust. The finding was confirmed by Lee and Wong [10]. Customers who felt protected were prone to have more trust to use the MTA application. Service providers should implement security standards that ensure the protection and security of the customers' data. Customer satisfaction had a significant impact on customer loyalty. Customers who were satisfied with the quality of the services provided were likely to re-purchase or re-use products and services from the same service provider [27][11][10] [9][22]. Customer satisfaction had a significant direct influence on trust [26][11][10]. Satisfied customers should form a bond with the service provider [38].

Trust had a positive effect on customer loyalty. In m-commerce, customer trust was significant [33]. Trust was the basis for establishing and maintaining relationships between customers and online retailers [33]. Trust had a significant effect on commitment. The effect of trust on commitment was more substantial than trust on customer loyalty [10]. The commitment had a significant influence on customer loyalty [5] [35]. Customer engagement had a positive impact on customer loyalty. Service providers needed to develop a strategy to support customer relationships [9][31][32]. Customers with positive financial transactions and access to information were more engaged with the service provider [9]. 


\subsection{Multigroup SEM}

The results of the Multigroup SEM path analysis are shown in Table 4. Based on Table 4, six hypotheses were rejected. These were H0-1a, H0-1b, H0-2a, H0-2b, H0-7, and H0-9. It indicates another relationship between the constructs caused by the differences in the sample group. Efficiency in the lower-middle-income group had a significant direct effect on customer satisfaction. It was different from that in the upper-middle groups (H01a). Respondents of lower-middle-income feel that efficiency was one of the factors affecting the satisfaction of the MTA application. This result proved the previous research that found the role of income in moderating the customer satisfaction model relationship [39]. Efficiency influenced trust in the lower-middle-income group (H0-1b). However, It did not have a positive influence on trust in the upper-middle groups. To lower-middleincome customer's efficiency, one of the service quality aspects impacted their trust in using the MTA application. However, their trust in using the MTA application was not influenced by efficiency for the upper-middle-income group. This study supported Bakar and Ilkan [19].

Table 4. Result of a hypothesis test for Multigroup SEM

\begin{tabular}{cccc}
\hline Hypothesis & Code & P-Value & Note \\
\hline EFF -> SAT & H0-1a & 0.0000 & Rejected \\
EFF -> TRU & H0-1b & 0.0147 & Rejected \\
FUL -> SAT & H0-2a & 0.0000 & Rejected \\
FUL -> TRU & H0-2b & 0.0003 & Rejected \\
CON -> SAT & H0-3a & 0.9588 & Accepted \\
CON ->TRU & H0-3b & 0.2094 & Accepted \\
RES -> SAT & H0-4a & 0.1899 & Accepted \\
RES ->TRU & H0-4b & 0.5988 & Accepted \\
PRI -> SAT & H0-5a & 0.2190 & Accepted \\
PRI -> TRU & H0-5b & 0.2543 & Accepted \\
SAT -> LOY & H0-6 & 0.8814 & Accepted \\
SAT -> TRU & H0-7 & 0.0100 & Rejected \\
TRU -> LOY & H0-8 & 0.8959 & Accepted \\
TRU -> COM & H0-9 & 0.0000 & Rejected \\
COM -> LOY & H0-10 & 0.2360 & Accepted \\
ENG -> LOY & H0-11 & 0.0694 & Accepted \\
\hline
\end{tabular}

Reliability/fulfillment did not influence customer satisfaction in lower-middleincome groups (H0-2a). However, efficiency influenced customer satisfaction for upper middle income. Upper middle-income groups were concerned about the reliability of the application in assessing overall quality. The Reliability affected their satisfaction with the MTA application. Higher-income individuals considered more factors to be satisfied [39]. Therefore, it was concluded that the income difference significantly affected the relationship between reliability and customer satisfaction. The result showed that reliability/fulfillment did not impact trust in both groups (H0-2b). However, Lower middle-income respondents showed lower reliability/ fulfillment effects on trust compared to upper-middle-income respondents. This different level of trust can be attributed to the overall lower level of trust between low-income groups [24]. 
Customer satisfaction influenced trust in the lower-middle-income group (H0-7). It indicated that only low-middle-income respondents were satisfied. The reason for this statement was that the lower-middle-income groups had more trust than the uppermiddle-income groups did [29]. However, regardless of whether they felt satisfied or not, they continued to trust the MTA application for upper-middle-income respondents because their data were protected. Trust had a significant impact on commitment in the two groups tested (H0-9). It can be concluded that the strength of trust in commitment was explained differently by the two groups [10].

\subsection{Managerial Implication}

In order to improve customer loyalty, service providers must pay attention to customer satisfaction, trust, commitment, and customer engagement. The dimensions of service quality, which consist of efficiency, reliability, fulfillment, responsiveness, and privacy/ security, must be maximized. However, their influence on customer loyalty is indirect. An excellent service must be provided to create customer satisfaction. Service providers may consider providing refunds, rescheduling online check-in, and two-step verification (for credit card transactions) features in their MTA applications. Differences in the relationship between the lower middle and upper-middle-income groups can be used to plan a business strategy. Strategies should be differentiated to represent the features of these two different groups.

\section{Conclusion}

Customer satisfaction, trust, commitment, and commitment were factors that had a significant impact on customer loyalty. Service providers must also pay attention to the quality of service measurements, consisting of efficiency reliability/fulfillment, responsiveness, and privacy/security to build customer satisfaction and trust. Another result was that variations in income levels might affect the relationship between variables in the study model. Grouping categories can further develop this study based on the level of using the MTA application. This analysis model can be developed by evaluating the interaction between customer satisfaction and responsibility for the same period. Another suggestion is to create a quality service assessment instrument that matches the characteristics of the Indonesian respondents and falls into mobile commerce research.

\section{References}

[1] eMarketer. (2014). 2 Billion Consumers Worldwide to Get Smart(phones) by 2016 eMarketer. Available: https://www.emarketer.com/Article/2-Billion-ConsumersWorldwide-Smartphones-by-2016/1011694.

[2] D. Cho, H. J. Kwon, and H. Lee, "Analysis of Trust in Internet and Mobile Commerce Adoption," in 2007 40th Annual Hawaii International Conference on System Sciences (HICSS'07), 2007, pp. https://doi.org/10.1109/HICSS.2007.76.

[3] Indonesia-Investments. (2017). Indonesia is the World's Fastest Growing MobileCommerce Market _ Indonesia Investments. Available: https://www.indonesiainvestments.com/id/business/business-columns/indonesia-is-the-world-s-fastestgrowing-mobile-commerce-market/item7802.

[4] APJII, Infografis: Penetrasi dan Perilaku Pengguna Internet Indonesia. Survei Internet APJII 2016: Polling Indonesia, 2016. 
[5] H.-H. Lin and Y.-S. Wang, "An examination of the determinants of customer loyalty in mobile commerce contexts," Information \& Management, vol. 43, pp. 271-282, 2006. https://doi.org/10.1016/j.im.2005.08.001.

[6] B. Keating, "Differentiating between service quality and relationship quality in cyberspace," Managing Service Quality: An International Journal, vol. 13, pp. 217 232, 2003. https://doi.org/10.1108/09604520310476481.

[7] C. Flavián, M. Guinalíu, and R. Gurrea, "The role played by perceived usability, satisfaction and consumer trust on website loyalty," Information \& Management, vol. 43, pp. 1-14, 2006. https://doi.org/10.1016/j.im.2005.01.002.

[8] T. Natarajan, S. A. Balasubramanian, and D. L. Kasilingam, "Understanding the intention to use mobile shopping applications and its influence on price sensitivity," Journal of Retailing and Consumer Services, vol. 37, pp. 8-22, 2017. https://doi.org/10.1016/j.jretconser.2017.02.010.

[9] R. Thakur, "Understanding Customer Engagement and Loyalty: A Case of Mobile Devices for Shopping," Journal of Retailing and Consumer Services, vol. 32, pp. 151-163, 2016. https://doi.org/10.1016/j.jretconser.2016.06.004.

[10] W. O. Lee and L. S. Wong, "Determinants of Mobile Commerce Customer Loyalty in Malaysia," Procedia - Social and Behavioral Sciences, vol. 224, pp. 60-67, 2016. https://doi.org/10.1016/j.sbspro.2016.05.400.

[11] A. N. Giovanis and P. Athanasopoulou, "Gaining customer loyalty in the e-tailing marketplace: the role of e-service quality, e-satisfaction and e-trust," International Journal of Technology Marketing, vol. 9, pp. 288-304, 2014. https://doi.org/10.1504/IJTMKT.2014.063857.

[12] N. S. Safa and M. A. Ismail, "A customer loyalty formation model in electronic commerce," Economic Modelling, vol. 35, pp. 559-564, 2013. https://doi.org/10.1016/j.econmod.2013.08.011.

[13] H. S. Ergün and Z. K. Kuşcu, "Innovation Orientation, Market Orientation and eLoyalty: Evidence from Turkish e-Commerce Customers," Procedia - Social and Behavioral Sciences, vol. 99, pp. 509-516, 2013. https://doi.org/10.1016/j.sbspro.2013.10.520.

[14] J. Choi, "Customer satisfaction factors of mobile commerce in Korea," Internet Research, vol. 18, pp. 313-335, 2008. https://doi.org/10.1108/10662240810883335.

[15] N. B. Pratama, S. K. Dewi, and T. Baroto, "Analisis Persaingan Dan Kepuasan Konsumen Dengan Menggunakan Metode Correspondance Analysis Dan Importance Performance Analysis," Jurnal Teknik Industri, Vol 16, pp. 78-82, 2017. https://doi.org/10.22219/JTIUMM.Vol16.No2.74-82.

[16] A. Susanty and A. C. Putra Buana, "Atribut-Atribut Yang Menjadi Prioritas Untuk Peningkatan Kualitas Layanan Di Patra Semarang Convention Hotel," Jurnal $\begin{array}{llllll}\text { Teknik Industri, } & \text { Vol } & \text { 12, } & \text { pp } & \text { 95-103, } & \end{array}$ https://doi.org/10.22219/JTIUMM.Vol12.No2.95-103.

[17] S. Kusuma Dewi, "Service Quality Assessment Using Servqual and Kano Models," Jurnal Teknik Industri; Vol 20, No 1 (2019): February, 2019. http://ejournal.umm.ac.id/index.php/industri/article/view/5456.

[18] E. Y. Huang, S.-W. Lin, and Y.-C. Fan, "M-S-QUAL: Mobile service quality measurement," Electronic Commerce Research and Applications, vol. 14, pp. 126142, 2015. https://doi.org/10.1016/j.elerap.2015.01.003.

[19] A. M. Abubakar and M. Ilkan, "Impact of online WOM on destination trust and intention to travel: A medical tourism perspective," Journal of Destination Marketing \& Management, vol. 5, pp. 192-201, 2016. https://doi.org/10.1016/j.jdmm.2015.12.005. 
[20] A. Parasuraman, V. A. Zeithaml, and A. Malhotra, "E-S-QUAL: A Multiple-Item Scale for Assessing Electronic Service Quality," Journal of Service Research, vol. 7, pp. 213-233, 2005. https://doi.org/10.1177/1094670504271156.

[21] R. Z. Y. Mohammad Al-Nasser, Rabiul Islam and Abdullah ALNasser, "E-Service Quality and its Effect on Consumers 'Perceptions Trust," American Journal of Economics and Business Administration, vol. 5, pp. 47-55, 2013. https://doi.org/10.3844/ajebasp.2013.47.55.

[22] M. J. López-Miguens and E. G. Vázquez, "An integral model of e-loyalty from the consumer's perspective," Computers in Human Behavior, vol. 72, pp. 397-411, 2017. https://doi.org/10.1016/j.chb.2017.02.003.

[23] M. Kim, Y. Chang, M.-C. Park, and J. Lee, "The effects of service interactivity on the satisfaction and the loyalty of smartphone users," Telematics and Informatics, vol. 32, pp. 949-960, 2015. https://doi.org/10.1016/j.tele.2015.05.003.

[24] P. R. Ward, L. Mamerow, and S. B. Meyer, "Interpersonal Trust across Six AsiaPacific Countries: Testing and Extending the 'High Trust Society' and 'Low Trust Society' Theory," PLOS ONE, vol. 9, p. e95555, 2014. https://doi.org/10.1371/journal.pone.0095555.

[25] C. H. Park, "Identifying key factors affecting consumer purchase behavior in an online shopping context," International Journal of Retail \&amp; Distribution Management, vol. 31, pp. 16-29, 2003. https://doi.org/10.1108/09590550310457818.

[26] J. L.-H. Bowden, "The Process of Customer Engagement: A Conceptual Framework," Journal of Marketing Theory and Practice, vol. 17, pp. 63-74, 2009. https://doi.org/10.2753/MTP1069-6679170105.

[27] M. Rafiq, H. Fulford, and X. Lu, "Building customer loyalty in online retailing: The role of relationship quality," Journal of Marketing Management, vol. 29, pp. 494517, 2013. https://doi.org/10.1080/0267257X.2012.737356.

[28] R. J. Brodie, A. Ilic, B. Juric, and L. Hollebeek, "Consumer engagement in a virtual brand community: An exploratory analysis," Journal of Business Research, vol. 66, pp. 105-114, 2013. https://doi.org/10.1016/j.jbusres.2011.07.029.

[29] G. Medve-Bálint, Zsolt Boda, "The Poorer You Are, the More You Trust? The Effect of Inequality and Income on Institutional Trust in East-Central Europe," Sociologický časopis / Czech Sociological Review, vol. 50, pp. 419-454, 2014. https://doi.org/10.13060/00380288.2014.50.3.104.

[30] M. Zhang, L. Guo, M. Hu, and W. Liu, "Influence of customer engagement with company social networks on stickiness: Mediating effect of customer value creation," International Journal of Information Management, vol. 37, pp. 229-240, 2017. https://doi.org/10.1016/j.ijinfomgt.2016.04.010.

[31] F. Demirci Orel and A. Kara, "Supermarket self-checkout service quality, customer satisfaction, and loyalty: Empirical evidence from an emerging market," Journal of Retailing and Consumer Services, vol. 21, pp. 118-129, 2014. https://doi.org/10.1016/j.jretconser.2013.07.002.

[32] G. G. Lee, "Customer perceptions of e-service quality in online shopping," International Journal of Retail \&amp; Distribution Management, vol. 33, pp. 161176, 2005. https://doi.org/10.1108/09590550510581485.

[33] J. Kim, B. Jin, and J. L. Swinney, "The role of retail quality, e-satisfaction and etrust in online loyalty development process," Journal of Retailing and Consumer Services, vol. $\quad 16, \quad$ pp. 2009. https://doi.org/10.1016/j.jretconser.2008.11.019. 
[34] R. E. Anderson and S. S. Srinivasan, "E-satisfaction and e-loyalty: A contingency framework," Psychology \& Marketing, vol. 20, pp. 123-138, 2003. https://doi.org/10.1002/mar.10063.

[35] A. Gustafsson, M. D. Johnson, and I. Roos, "The Effects of Customer Satisfaction, Relationship Commitment Dimensions, and Triggers on Customer Retention," Journal of Marketing, vol. 69, pp. 210-218, 2005. https://doi.org/10.1509/jmkg.2005.69.4.210.

[36] N. M. Kassim and N. A. Abdullah, "Customer Loyalty in e-Commerce Settings: An Empirical Study," Electronic Markets, vol. 18, pp. 275-290, 2008. https://doi.org/10.1080/10196780802265843.

[37] V. M. Kumbhar, "Factors Affecting On Customers' Satisfaction In E-Banking: Some Evidences Form Indian Banks," Management Research and Practice, vol. 3, pp. 114, 2011. https://ideas.repec.org/a/rom/mrpase/v3y2011i4p1-14.html.

[38] C.-J. Liang and H.-J. Chen, "A study of the impacts of website quality on customer relationship performance," Total Quality Management \& Business Excellence, vol. 20, pp. 971-988, 2009. https://doi.org/10.1080/14783360903181784.

[39] S. Yol, A. Serenko, and O. Turel, Moderating Roles of User Demographics in the American Customer Satisfaction Model within the Context of Mobile Services vol. 17, 2006. http://aisel.aisnet.org/amcis2006/245. 